\title{
Correlation Between the Relation to Work and Social Intelligence Among the Mayors in the Slovak Republic
}

\author{
Eliška ŽUPOVÁ ${ }^{1}$
}

\begin{abstract}
The aim was to identify the relationship between the relation to work and social intelligence according to its individual factors. The subject of the research was the mayors of municipalities in Slovakia. The survey was attended by 787 mayors from a total of 2,753 (28.5\%). To obtain the empirical data, a standardized social intelligence questionnaire based on MESI's psychometric approach was used, and the questionnaire finds a relationship with Job Satisfaction Instrument (JSI). The results of the research were processed using the SPSS 21 statistical software. To test the nature of relationships and dependencies between variables and to test the tightness of the relationship between the studied variables, a correlation analysis was used using the Pearson correlation coefficient, which expresses the degree of tightness of the linear relationship between the two (interval) variables. Research has found that the higher the rate of social irritability the mayor has, the more positive is his relationship to the job.
\end{abstract}

Keywords: relationship to work, performance, social intelligence

\section{Introduction}

Most author definitions define social intelligence positively, such as the ability to act wisely in interpersonal relationships, the ability of a positive social interaction for both sides. Relation to work in terms of activity is the conscious attitude of a person, which is created by family upbringing, cultural and social values and the support of the organization. Relation to work as an attitude is reflected in its positive or negative direction. According to scientific knowledge and the results of previous research, the ability to cope with the social environment needs a high degree of social intelligence which is one of the factors of job satisfaction and positive relation to work.

\section{Social Intelligence}

The set-up of social intelligence was first defined by Thorndike as "the ability to understand and manage other people and to act wisely in interpersonal relations.” [58: 229] The author, in his definition, has lent himself to the two-factor structure of the definition of social intelligence and within this structure he distinguishes cognitive elements (people of social intelligence) and behavioural elements (wise behaviour in interpersonal relationships).

Ph.D., Assistant Professor, Pavol Jozef Šafárik University in Košice, Faculty of Public Administration,

Department of Social Studies; e-mail: eliska.zupova@upjs.sk 
This is also understood as an ability to understand other people and social interactions and to apply this knowledge in leadership and influencing other people for mutual satisfaction. [39]

According to others (for example) [41] [28], social intelligence is defined as the ability to purposefully address various social problems, with social intelligence as a specific phenomenon, relatively independent of general intelligence, consisting of two components:

- perceptive- the ability to understand other people, the ability to know the other person and to choose the appropriate behaviour towards him/her, respecting the particularities noted;

- action, behavioural - the ability to act wisely in interpersonal relationships, a way of social behaviour that fulfils a particular intention of an individual.

Social intelligence also has its negative charge in the form of manipulative behaviour. The authors point out that social intelligence consists of perceptions about the inner states and moods of others, the general ability to deal with other people, knowledge of social standards and social life, the ability to orient themselves in social situations, the use of social techniques to manipulate, the ability to interact with other people, social attractiveness and social adaptation. [54] Social intelligence is an intelligence focused on the social world. [27]

Social intelligence has a very close relation to emotional intelligence because it describes two aspects of the same construct. The most existing definitions of social and emotional intelligence include one or more of the following abilities: to understand and constructively express emotions, [38] to understand the experience of other people and to create cooperative interpersonal relationships, to effectively manage and regulate emotion, to realistically manage new situations and to solve problems of personal or interpersonal nature, be optimistic, positive and internally motivated, as well as formulate and achieve goals. [5]

Emotional intelligence is part of social intelligence. [5] It is defined as the ability of man to control his emotions and the emotions of others, the ability to distinguish between emotions and to use social information to regulate thought and action. The authors described components of emotional intelligence such as:

- the perception of emotions;

- using emotions;

- understanding emotions;

- managing emotions.

Emotional intelligence is known by defining its content in 5 basic dimensions, namely:

a) ability to self-reflection (willingness and ability to think about oneself, to recognize oneself, strengths and weaknesses);

b) self-control (ability to adequately express emotions);

c) motivation (ability to excite others about an activity, engagement, creating a positive image of the world);

d) empathy (the ability to understand others, to feel their feelings in the workplace which is also important for customer orientation, multicultural sensitivity, ability to lead subordinates and work in a team);

e) social competency (ability to manage different forms of human interaction through communication, conflict resolution, respect of social norms and rules, achievement of socially preferred goals, etc.). 
Rational intelligence, referred to as rational intelligence is considered to be a basic prerequisite for the success of a person in all activities performed; it also forms the basis for the general readiness of a person to understand the roles and situations. The basic premise of efficient use of rational intelligence is emotional intelligence. It is more important than general intelligence, because in order to achieve an intelligent management of the demands of contemporary life, general intelligence is not enough. [28]

It is necessary to recognise social intelligence as one of the important predictors of effective behaviour of managers. Knowledge of social intelligence makes it possible to predict the manager's success in social contacts. [40] In order for managers to be successful in their work, they must know about the nature of their work and their activities at least as much as they know about their professional duties. It is necessary to realize that the manager is the person on whom the success of the whole society depends. This means that when selecting people for managerial positions, attention should be paid to the ability of a future wise and correct negotiation in interpersonal relationships. [26]

The concepts of social intelligence and social competency are very close. The basic difference is the importance of the set-up of social intelligence, which is used in a positive, neutral and negative sense, and in addition to the cognitive component it also contains a behavioural component. A person with a high degree of social intelligence can behave sacrificially and empathically, but he can also use people to his advantage using manipulative techniques. The form of social intelligence (or a negative manipulative or empathic attitude) depends on the circumstances of the situation, but also on the characteristics and character of the individual. Social competency involves only a positive significance in order to achieve positive social relations, social behaviour. It is therefore possible to characterise a high level of social competency as the ability to use interpersonal (social) subcomponents in order to fulfil the expected (desirable) social behaviour. Social competency and social intelligence are understood as a multidimensional structure.

The concepts of social intelligence, emotional intelligence and social competency are interpreted very similarly by the authors. Until the present day, there is no uniformly accepted definition that would correspond to the real phenomenon of social intelligence and social competency. The differences, resp. similarities of the structure of social competency and social intelligence is not the subject of our discussion. Social competency represents certain predispositions of the individual - the ability to develop and train through education and gain experience. Social intelligence involves a component of social competency and a component of behaviour-it manifests itself in behaviour.

Social competency has been defined as social dexterity in terms of a certain skill to pursue its objectives in social interaction. [4]

Social competency was characterized by Cavell [21] as an effective social behaviour. Guralnik describes social competency as the ability to successfully and adequately choose and implement interpersonal goals. [29]

To achieve success in the social and working world, social competency is fundamental. Kollárik said in defining social competency that it is a skill that unconditionally should be available to an individual-an employee who interacts with clients in different situations, fulfilling his requirements and providing services. [35]

Social competency is defined as the ability to induce and maintain satisfying human relationships. [33] Social competency seems a "dexterity and efficiency in social interaction 
with people, based on respect for human dignity.” [55: 45] Defining dexterity the author includes the ability to establish contacts, cooperative behaviour and also to reduce tension. The core of effectiveness is the achievement of goals, the ability to identify the social problem, and then to infer tactics in it, the ability to solve the problem, the ability to get a partner to cooperate or compromise.

Social competency is the ability of a person to appropriately promote himself/herself in social relationships, as well as to his/her loved ones, as well as to the conditions of his/her inclusion in society. The socially oriented individual is able to understand the necessity, but also the benefits of accepting his/her surroundings. [7] He/she knows how to adapt to others by preserving his/her individuality. Social competency is perceived more narrowly defined as a set of communication skills. [49]

When defining social intelligence, it is necessary to distinguish how an individual understands, interprets his/her own behaviour, other people's behaviour, and the way to behave efficiently - socially intelligently and act accordingly. Social competency is the ability of an effective and consistent [18] behaviour in order to achieve the goals, i.e. socially responsible behaviour. By Hupková's opinion developing socially responsible behaviour means improving self-reflection, social process reflection, social competency training as defined. [30] “... social competency in itself contains an a priori positive connotation in contrast to socially intelligent behaviour, which may have a manipulative, antisocial character". [44: 308] Social competency is a component of emotional intelligence. [43]

For knowledge and intervention, it is useful to know the contents of these psychological structures, often used and studied in management.

Social intelligence is defined by scholars as an ability to understand people, [39] [54] to be able to cooperate well with them, to maintain viable relationships that are useful to all actors. Social intelligence is the irreplaceable ability of the mayor of the municipality.

According to scientific knowledge, the ability to cope with the social environment is one of the factors of job satisfaction and a positive relationship to work. [22] [53]

Individuals with a higher level of social intelligence have the ability to recognize and reduce stress, understand the causes of stress, recognize conflict situations in the workplace and manage to solve them. They have the ability to recognize and control their emotions, achieve a higher level of self-confidence and self-awareness, have a positive influence on others, enhance positive emotions among the members of the working group, and thus increase the positive attitude towards their work as well as members of the working group.

Individuals with a low level of social intelligence are less aware of their emotions, have less ability to cope with stressful and conflicting situations. This inability reduces their job satisfaction and positive relationship to work.

\section{Relationship to Work}

Relation to work in terms of activity is the conscious attitude of a person, which is created by family upbringing, cultural and social values, and the support of the organization. Relation to work in terms of profession is linked to a particular individual because it determines the characteristics of the personality (abilities, interests, temperament and character) and the taste to carry out this work affects the organization (e.g. by stimulation, communication, 
interpersonal relationships, leadership and leadership of the manager, work environment and technology). Relation to work as an attitude is reflected in its positive or negative direction.

There are four main forms of work relation. Relationship to work is of such making that creates society (community). [51] Furthermore, it is the relationship between work and occupation that is being prepared (career choice) and which one chooses. Richard Finn also defines the relation to the current work, which characterizes the taste, or the reluctance to work and, above all, this type of relationship affects the organization. It also defines the relation to the work previously done, which is formed by memoirs. As a rule, it is positive, because one tends to forget about unpleasant experiences. [25]

Relation to work greatly determines the job satisfaction. It is considered to be one of the most important working attitudes and an indicator highlighting the level of human equilibrium with work and its conditions. [47]

Work satisfaction is "a collective attitude, the formation of which involves partial attitudes towards individual aspects, a sign of work." [34: 56] It is a complex phenomenon that involves and combines objective factors-working conditions, external factors of the environment on the widest scale-and subjective factors related to the values of individuals, their needs, the level of motivation. In essence, the relationship between the individual and the outside world is the result of a serious psychic phenomenon. Work satisfaction is the response of an individual to work experience. [8] Satisfaction as an attitude towards work is reflected in the overall life satisfaction of a person and adequate integration into society. [36]

If the impact of these attitudes is positive, we are talking about a positive relationship to work. If it is negative, we are talking about a negative relationship to work. [8]

The main manifestations of a positive relationship to work are moral responsibility for work (adequate, expected fulfilment of duties), positive emotional relation to work, which is manifested by satisfaction, good mood, pleasure and employment, discipline, guidelines, standards, an initiative that presents itself with working willingness, entrepreneurship and creativity, worker activity and good quality of work. On this basis, a positive relationship to work can be defined as a favourable or positive emotional state resulting from the assessment of work or work experience. On the other hand, the negative relationship to work is manifested in particular by the moral irresponsibility of the work done (indifference), the negative emotional relation to work (dissatisfaction, disappointment), lack of competency, lack of initiative (avoidance of work), low activity (passivity, laziness, reduction of the working time), poor quality of work (non-behaviour, error, inefficiency). [51]

The positive attitude towards work manifests itself in an overall working behaviour, activity and willingness to work, with an effort to initiate tasks, satisfaction with working conditions and a positive orientation towards work and performance. [48] The negative attitude towards work is reflected in reluctance, when we do not want to be successful, persistent dissatisfaction with working conditions, inclination towards fluctuation, tendency to disturb relationships, conflicting behaviour, and negative orientation to work and performance. [36] The influence of the relationship with work points out that the relationship of man to work is formed over a long period of time, also through what man gives to work, how he perceives it and can manifest in different ways. In terms of work activity, the attitude of a person is therefore important to the work in general, but also to the work done. If the relationship is positive, work satisfies him/her, there is the possibility of self-realization, work does not burden him, he/she is active, creative, which also positively affects work performance. 
In a negative relationship to work, it is the opposite. Man considers work to be evil, therefore he/she does not work properly and considers his/her performance burdensome. [24]

There is a significant relationship between work satisfaction and organizational devotion where one cannot exist without one another. To achieve a high level of job satisfaction, managers need to know and understand what their employees want from work, thereby contributing to increased job satisfaction and reduced job satisfaction. [19]

Survey conducted on a sample of 180 agents at the Mississippi State University Extension Service has shown that those individuals who show high job satisfaction are more concerned with the quality of work done and are more devoted to the organization. [37] According to the results of the study, there is no statistically significant relationship between sex and relationship to work. The research results further showed that there is no statistically significant relationship between the relationship to work and the personality type (the Myers Briggs Type Indicator - MBTI questionnaire). However, the results of the study confirmed that age affects work satisfaction. Older and more experienced individuals show greater job satisfaction and are more dedicated to the organization than younger and less experienced individuals.

According to research, [31] [42] there is evidence that there is a significantly positive relationship between engagement and performance. It states that these employees are more efficient employees.

The relationship between work environments examined characteristics and attitudes towards work. A relationship was found between salary, work experience, teamwork and job satisfaction. They point out that the higher the pay, the work experience the richer together with the informal relationships in the working group, so job satisfaction is higher and the job relationship is more positive, which applies equally to men and women. [23]

The impact of the relationship with work on the performance of the employee is shown in the results, which states that a positive relationship to work brings satisfaction from work and an increase in work performance. [6]

\section{Aim and Object}

The aim of the research was to analyse the connection between the relation to work and social intelligence (empathy, manipulation, social irritability) among mayors of municipalities in the Slovak Republic.

As a hypothesis it is assumed the existence of a connection between the relation to work and social intelligence (empathy, manipulation, social irritability) among mayors of municipalities in the Slovak Republic.

The subject of the research is social intelligence and relationship to work.

Objects of the research are the mayors of municipalities in the Slovak Republic.

Local self-government is carried out in Slovakia on two levels, namely by municipalities and higher territorial units. There are 2,753 municipalities in Slovakia (31 January 2015source: Statistical Office of the Slovak Republic). [57] At the head of the municipality, the municipal mayor is elected by the mayor of the municipality for a four-year term of office. The mayor of the municipality is an elected local government official who is expected to be willing and have a professional attitude towards work for the development 
of the municipality, as well as the needs and interests of its inhabitants. In the mayor's office, the performance of municipal self-government and local government is linked. [45] [46]

The mayor, as one of the bodies of the municipality, is governed by Act No. 460/1992 Coll. The Constitution of the Slovak Republic in Art. 69, which states that "the mayor of the municipality is the executive body of the municipality; administers the municipality and represents the community externally.” [59] The position of the mayor is also regulated by Act No. 369/1990 Coll. on the general establishment, [60] Act No. 253/1994 Coll. on the legal status and salary of mayors of municipalities and mayors of cities, which in para. 2 says that the function of the mayor of the municipality is a public function which is not performed in the employment relationship, i.e. there is no working relationship between the elected mayor and the municipality. [61] Therefore, the mayor does not have a summary of the duties he has to carry out. Its position is characteristic of the performance of the function. According to para. 13 (1) of the Act on General Settlement, the execution of the duties of the mayor is considered to be a public function.

However, the mayor of the municipality does not establish an employment relationship, but the mayor's job defines the tasks he performs on a daily basis in the performance of his duties. It is important for the mayor to achieve a high level of quality work performance. To achieve an optimal level, a positive relationship to work as a performance determinant is necessary. Prosperity and community performance depend to a large extent on the relationship of the mayor to the job and to the function performed.

\section{Methods}

The standardized MESI (Manipulation, Empathy, Social irritability) questionnaire was used. It is set up by Frankovský and Birknerová, explores the degree of social intelligence based on psychometric approach in its three factors-empathy, manipulation, and social irritability - in order to obtain empirical data and verify the established hypothesis. [12-17] The questionnaire contains 21 items. The respondent is speaking on a 5-degree scale. The scale anchors vary from 1 never to 5 -very often. The score achieved can range from 7 to 35 points for each factor, where 7 points represent a low level of the Social Intelligence Factor and 35 points to a high level of the Social Intelligence Factor. The reliability of the MESI questionnaire shows the calculated Cronbach alpha $\alpha=0.79$. Reliability of individual factors demonstrates Cronbach alpha values: manipulation $\alpha=0.831$, empathy $\alpha=0.857$, social irritability $\alpha=0.799$. The authors report the reliability of the individual factors: manipulation $\alpha=0.845$, empathy $\alpha=0.772$, social irritability $\alpha=0.725$.

The standardized Job Satisfaction Instrument (JSI) [20] was used to measure the relationship to work; the authors are Brayfield and Rothe. This standardized questionnaire finds a relationship with work and has been used for a very long time since 1951 . The questionnaire contains 18 statements expressing the attitude of an individual to his work, of which 9 statements are formulated in reverse. Relation to work is detected on a 5-degree scale. The anchors range from 1 -completely disagree (i.e. the respondent disagrees with the statement) up to 5-completely agree (i.e. the respondent agrees with the statement). The score achieved can range from 18 to 90, with 18 points strongly negative to work, and 90 points have a strong positive relationship to work. The questionnaire reliability shows that 
the Cronbach alpha values are $\alpha=0.80$. The authors reported questionnaire reliability is $\alpha=$ 0.87 .

\section{Statistical Analysis}

The results of the research were processed using the SPSS 21 statistical software. To test the nature of relationships and dependencies among variables and to test the tightness of the relationship among the studied variables, a correlation analysis was used using the Pearson correlation coefficient, which expresses the degree of tightness of the linear relationship between the two (interval) variables. Through the analyses, we have respected the conditions of use of individual methods.

\section{Results}

The aim was to find out the connection between the relationship to work and social intelligence according to its individual factors-empathy, manipulation and social irritability among the mayors of municipalities in the Slovak Republic.

On the basis of the theoretical knowledge, we have formulated the assumption of the existence of links between the relationship to work and social intelligence among the mayors of the municipalities. To obtain the results, Pearson's correlation coefficient (r) was used.

Table 1. The correlation between the relationship to work and social intelligence.

[Edited by the author]

\begin{tabular}{|l|c|c|c|}
\hline Item & Empathy & Manipulation & Irritability \\
\hline relationship to work & $-0.325^{* *}$ & 0.009 & $0.274^{* *}$ \\
\hline
\end{tabular}

**(probability value - significance level) $\mathrm{p} \leq 0.01$; weak correlation $< \pm 0.29$; middle correlation $\pm 0.30- \pm 0.49$, strong correlation $\pm 0.50- \pm 1.0$.

\section{Discussion}

There is a significant relationship between the two factors of social intelligence, namely empathy and irritability, and the relationship to the function of mayors (Table 1). Significant relationship was not confirmed between manipulation and relationship to work. The findings confirmed the results of several studies, for example [1] [2] [32].

There is a moderately positive relationship between social irritability and workrelatedness, where $r=0.274, \mathrm{p}<0.01$. The higher the rate of social irritability the mayor gets, the more positive the relationship to the job. Mayors who are characterized by a higher score in the factor of social irritability may make nervous contact with other people. They are socially isolated, they limit social contacts with people. Their presence is irritating, they prefer performing their work independently. They may think they are pursuing their job 
at the expense of social relations. And it can also be assumed that a high degree of social irritability predicts the individual work focus of the mayor.

Based on the results of the validation of the MESI questionnaire on the TSIS (The Tromsø Social Intelligence Scale) methodology-a socially irritable individual has a low level of social intelligence. The results of the positive correlation between low levels of social intelligence and work-relatedness are consistent with the results of the research. [3]

A surprising result is the existence of a significantly moderate negative relationship between empathy and work-relatedness. where $r=-0.325, \mathrm{p}<0.01$.

More empathetic individuals experience a higher level of social well-being and at the same time their feeling that they are part of the society and community they live in is stronger. They feel they are important and beneficial for the community and have positive feedback. Mayors scrutinizing the empathy factor know how to recognize the intentions, feelings and weaknesses of other people. I can adapt the concession to people because they are geared to maintaining good interpersonal relationships. [9] [10] [11] They are spontaneously and completely naturally comfortable in the feelings of others, they know how to estimate their problems (both personal and work-problems), while willing to meet these problems and wishes. They can estimate how well people have to adapt and prefer good interpersonal relationships at the expense of work performance. As a result of such a process, it is in our results that we have a negative attitude towards avoiding the work done. [56]

It was found that a higher empathy rate increases the level of work satisfaction and contributes to a positive relationship to work, which does not coincide with our findings. [50] But we have confirmed the results of research that empathy negatively correlates with the relationship to work. [52]

It was found that empathy is negatively related to the relationship to work (the higher the empathy score, the more negative the relationship to work), and that work-related irritability is positively related, while the socially irritable individual possesses a low level of social intelligence that we consider necessary to perform the function of the mayor.

At the same time, it can be said that a low empathy rate and a high rate of social irritability predict individual work orientation, increase work-relatedness, and reduce the level of human orientation and relationships.

The result of statistical testing confirmed the hypothesis only partially. There is a relationship between the factors of social intelligence empathy, social irritability and the relationship to work with mayors of municipalities. There is no relationship between factor manipulation and work relationship with mayors of municipalities.

\section{Conclusion}

The results confirmed the relationship between social intelligence in the factors of empathy and social irritability and the relationship with the work of mayors of municipalities. It was found out that:

- the higher the degree of social irritability the mayor achieves, the more positive it is to work. A high degree of social irritability in the mayor of the municipality means inability to act socially, but at the same time indicates a more positive relationship 
to work. A socially irritable individual has a low level of social intelligence which we consider necessary for the mayor's office;

- the higher the degree of empathy the mayor has, the more negative the relationship to the job. At the same time, it can be said that a low empathy rate and a high rate of social irritability predict individual work orientation, increase work-relatedness, and reduce the level of human orientation and relationships.

Based on the results, the author of research recommends:

- further exploration of interpersonal competency, social intelligence, and performance relationship. The results are not exhaustive for this explored issue and outline further possible research focus - for example, exploring the motives to serve as mayor of the municipality;

- the self-assessment of the mayors' own degree of social irritability and the subsequent consideration of one's suitability for performance by the mayor and prospective candidate.

\section{References}

[1] AKBAR, R., AHAD, K.: The relationship between social intelligence managers with job satisfaction of teachers in schools. Journal of Educational Sciences, 27 (2009), 121-145.

[2] ALBRECHT, K.: Social Intelligence: The New Science of Success. San Francisco: JosseyBass, 2006.

[3] AMIRKABIRI, Ahsan et al.: Evaluation of emotional intelligence and job satisfaction in Islamic Republic of Iran Abroad Broadcasting Organization Department employees. Journal of Management Missionary, 2 (2011). 33-53.

[4] ARGYLE, M.: Social skills and health. London: Routledge, Taylor and Francis Group, 1981.

[5] BAR-ON, R. The Bar-On model of emotional-social intelligence (ESI). FernándezBerrocal. Special issue on emotional intelligence. Psicotherma, 178 (2005), 1.

[6] BATEMAN, T., ORGAN, D.: Job Satisfaction and the Good Soldier: The Relationship Between Affect and Employee “Citizenship.” Academy of Management Journal, 26 (1983), 587-595. https://doi.org/10.5465/255908

[7] BEDRNOVÁ, E., JAROŠOVÁ, E., NOVÝ, I.: Psychologie a sociologie řízení. Praha: Management Press, 1998.

[8] BERRY, L. M.: Psychology at work: An Introduction to Industrial \& Organizational Psychology. McGraw-Hill International Editions, 2009.

[9] BAUMGARTNER, F.: Emočná inteligencia v kontexte interpersonálnej interakcie. In. Sociálne kompetencie manažéra: teoretické, metodologické a praktické koncepty. Zborník recenzovaných štúdií z vedeckého seminára. Prešov: Prešovská Univerzita v Prešove, Katedra manažérskej psychológie, Fakulta manažmentu, 2012.

[10] BAUMGARTNER, F., VASIL’OVÁ, K.: K problematike merania sociálnej inteligencie. In. Sociální procesy a osobnost. Brno: Psychologický ústav AV ČR, 2005. 8-16. 
[11] BAUMGARTNER, F., ZAHAROVÁ, Z.: Emocionálna a sociálna inteligencia vo vztahu k zvládaniu v ranej adolescencii. E-psychologie, 2011.http://e-psycholog.eu/pdf/ baumgartner-etal.pdf (Downloaded: 19.01.2016)

[12] BIRKNEROVÁ, Z.: Emočná inteligencia v kontexte interpersonálnej interakcie. In. Sociálne kompetencie manažéra: teoretické, metodologické a praktické koncepty. Zborník recenzovaných štúdií z vedeckého seminára. Prešov: Prešovská Univerzita v Prešove, Fakulta manažmentu, Katedra manažérskej psychológie, 2012.

[13] BIRKNEROVÁ, Z., IVANKOVÁ, A.: Vnímanie a riešenie konfliktných situácií na pracovisku. In. Sociálne javy v kultúrnom a osobnostnom kontexte. Nekonferenčný vedecký zborník recenzovaných štúdií s medzinárodnou účastou. Prešov: Prešovská Univerzita v Prešove, Fakulta manažmentu, Katedra manažérskej psychológie, 2013.

[14] BIRKNEROVÁ, Z., JANOVSKÁ, A.: Analýza súvislostí medzi sociálnou inteligenciou a sociálnou pohodou budúcich manažérov. In. Psychologie práce a organizace 2013. Sborník př́spěvku. Olomouc: Univerzita Palackého v Olomouci, 2013. 159-166.

[15] BIRKNEROVÁ, Z., KENTOŠ, M.: Emocionálna a sociálna inteligencia manažérov a výkonných pracovníkov. Journal of Management and Business: Research and Practice, 32 (2011), 18-28.

[16] BIRKNEROVÁ, Z., FRANKOVSKÝ, M.: Sociálna inteligencia v kontexte manažérskej práce. Prešov: Bookman, 2013.

[17] BIRKNEROVÁ, Z., FRANKOVSKÝ, M.: Zist’ovanie sociálnej inteligencie metodikou MESI. Člověk a spoločnost', SAV. 2014.

[18] BOYATZIS, E. R.: The competent manager: A model for effective performance. New York: John Wiley \& Sons, Inc., 1982.

[19] BOWEN, C. F., RADHAKRISHNA, R., KEYSER, R.: Job satisfaction and commitment of 4-H agents. Journal of Extension, 321 (1994). www.joe.org/joe/1994june/rb2.html (Downloaded: 27.08.2005)

[20] BRAYFIELD, A., ROTHE, H.: An Index of Job Satisfaction. Journal of Applied Psychology, 355 (1951), 307-31.

[21] CAVELL, T.: Social adjustment, social performance, and social skills: A tricomponent model of social competence. Journal of Clinical Child Psychology, 192 (1990), 111-122.

[22] COOPER, R., SAWAF, A.: Executive EQ: Emotional intelligence in leadership and organizations. New York: Grosset/Putnam, 1997.

[23] EMADI, A. et al.: Studying the factors affecting job satisfaction of employees of Semnan health centers. Journal of Paramedical Sciences, 6 (2015), 87-91.

[24] FLEŠKOVÁ, M., DOLINSKÁ, V.: Aplikovaná psychológia pre ekonómov a manažérov. Bratislava: Iura Edition, 2010.

[25] FINN, R.: A Synthesis of Current Research on Management Competencies. London: Brunel University of West London, Henley Management College, 1993.

[26] FRANKOVSKÝ, M., FEČ, P.: Sociálna inteligencia v kontexte manažérskych kompetencií vymedzených lancasterským modelom. Psychologie práce a organizace 2013. Sborník př́spěvku. Olomouc: Univerzita palackého v Olomouci. 159-166.

[27] FRANKOVSKÝ, M., BARANOVÁ, M.: Social Intelligence in Managerial Competence. Management 2010. (part II): knowledge and management in times of crisis and ensiung development. Prešov: Prešovská univerzita v Prešove, 2010. 721-731.

[28] GOLEMAN, D.: Emoční inteligence. Praha: Columbus, 1997. 
E. ŽUPOVÁ: Correlation Between the Relation to Work and Social Intelligence...

[29] GURALNIK, M.: Social competency and early intervention. Journal of Early Intervention, 141 (1990), 3-14. https://doi.org/10.1177/105381519001400101

[30] HUPKOVÁ, M.: Sociálna kompetencia a možnosti jej kultivácie v podmienkach univerzity tretieho veku. Paidagogos, 2 (2013), 90-106. www.paidagogos.net/issues/2013/2/article. php?id=7 ( Downloaded: 23.02.2015)

[31] IMRAN, A. H. et al.: The Impact of Employee Empowerment on Job Satisfaction Theoretical Study. American Journal of Research Communication, 2 (2014), 13-26.

[32] JELOUDAR S.Y., GOODARZI, F. L.: The Relationship between Social Intelligence and Job Satisfaction among MA and BA Teachers. International Journal of Educational Sciences, 43 (2012), 209-213. https://doi.org/10.1080/09751122.2012.11890044

[33] KNIGHT, B., HUGHES, D.: Developing social competence in the preschool years. Australian Journal of Early Childhood Education, 20 2(1995), 13-19.

[34] KOLLÁRIK, T.: Psychologické aspekty pracovnej spokojnosti. 1. vyd. Bratislava: Psychodiagnostické a didaktické testy, 1979.

[35] KOLLÁRIK, T.: Sociálna psychológia. Bratislava: Univerzita Komenského v Bratislave, 1993.

[36] KOLLÁRIK, T., LISÁ, E., RITOMSKÝ, A.: Psychodiagnostika manažérov. Učebnica pre vysoké školy. 1 vydanie. Žilina: Eurokódex, 2013.

[37] LONG, L. J., SWORTZEL, K. A.: Factors influencing job satisfaction of extension agents in the Mississippi State University Extension Service. Proceedings of the 2007 AAAE Research Conference. Minneapolis, Minnesota, 2007.

[38] MARLOWE, H.: Social intelligence: Evidence for multidimensionality and construct independence. Journal of Educational Psychology, 78 (1986), 52-58.

[39] MARLOW, S., PATTON, D., RAM, M.: Managing Labour in Small Firms, Routledge Studies in Small Business. London, 2004.

[40] MAYER, J., SALOVEY, P.: Emotional intelligence. 1990. www.unh.edu/emotional_ intelligence/EIAssets/EmotionalIntelligenceProper/EI1990\%20Emotional\%20Intelligence. pdf (Downloaded: 12.02.2015) https://doi.org/10.2190/DUGG-P24E-52WK-6CDG

[41] NAKONEČNÝ, M.: Encyklopedie psychologie. Praha: Academia, 1998.

[42] NEWMAN, A., SHEIKH, A. Z.: Organizational commitment in Chinese smalland medium-sized enterprises: the role of extrinsic, intrinsic and social rewards.

The International Journal of Human Resource Management, 23 (2012), 349-367.

[43] OROSOVÁ, O., KLOBUŠNÍKOVÁ, V.: Sociálno-psychologické spôsobilosti učitelov. In. BAUMGARTNER, F., FRANKOVSKÝ, M., KENTOŠ, M. (zost.): Sociálne procesy a osobnost. Košice: Spoločenskovedný ústav Slovenská Akadémia Vied, Ústav experimentálnej psychológie, 2002. 223-229.

[44] OROSOVÁ, O. et al.: Sociálna inteligencia, sociálna kompetencia - definície a prístupy v ich skúmaní. Československá psychologie, 484 (2004), 306-311.

[45] PALÚŠ, I., HENCOVSKÁ, M.: Vzt’ah demokracie a odbornosti v obecnej samospráve z pohladu starostov obcí. In. Zborník príspevkov z medzinárodnej vedeckej konferencie Teória a prax verejnej správy. Košice: Univerzita Pavla Jozefa Šafárika v Košiciach, Fakulta verejnej správy, 2013. 260-267.

[46] PALÚŠ, I., HENCOVSKÁ, M.: Starosta obce ako orgán verejnej moci. In. Viazanost' verejnej správy právom. Zborník vedeckých prác. Košice: Univerzita Pavla Jozefa Šafárika v Košiciach, Fakulta verejnej správy, 2013. 30-45. 
[47] PAULÍK, K.: Pracovní zátěž vysokoškolských učitelů. Ostrava: Repronis. 1995.

[48] RANKIN, N.: Raising performance through people, the ninth competency survey. Competency and Emotional Intelligence, 01 (2002), 2-21.

[49] RIGGIO, R., CARNEY, D.: Social skills inventory manual. Menlo Park: Mind Garden, 2007.

[50] ROGERS, J. et al.: Increasing job satisfaction of service personnel. Journal of Services Marketing, 8 (1994), 14-26. https://doi.org/10.1108/08876049410053267

[51] ROSINA, J.: Pracovná motivácia a vztah k práci. Bratislava: SPN, 1968.

[52] RUSNIFAEZAH, M. et al.: Influence Factors on Job Satisfaction among Malaysia Educator: A Study of UUM Academic Staffs. American Journal of Economics, 632 (2012), 251-256.

[53] SHIMAZU, A., SHIMAZU, M., ODAHARA, T.: Job control and social support as coping resources in job satisfaction. Psychological Reports, 942 (2004), 449-456.

[54] SILVERA, D. H., MARTINUSSEN, M., DAHL, T.: The Tromso Social Intelligence Scale, a self- report measure of social intelligence. Scandinavian Journal of Psychology, 42 (2001), 313-319. https://doi.org/10.1111/1467-9450.00242

[55] SMÉKAL, V.: Sociální kompetence (socialně psychologická způsobilost) a její rozvíjení. Psychologické texty. Brno: PsÚ, FFMU, 1995.

[56] SY, T., TRAM, S., O’HARA, L.: Relation of employee and manager emotional intelligence to job satisfaction and performance. Journal of Vocational Behavior, 68 (2006), 461-473.

[57] Fakty o zmenách v živote obyvatelov SR. Bratislava: Statistical Office of the Slovak Republic, 2014. 103-104.

[58] THORNDIKE, E. L.: Intelligence and its use. Harpers Magazine, 140 (1920), 227-235.

[59] Act No. 460/1992 Coll. Constitution of the Slovak Republic as amended by later amendments and provisions.

[60] Law No. 369/1990 Coll. the Act on General Settlement, as amended.

[61] Act No. 253/1994 Coll. on the legal status and salary of mayors of municipalities and mayors of cities, as amended. 